\title{
Enhancement of the knowledge on the drop in levels in Benin's high schools and colleges: Case of Fonkpamè College
}

\author{
AITCHEDJI Magloire Fortuné Landry", HOUEHA Noukpo Saturnin, KELANI R.Raphael \\ Ecole Normale Supérieure de Natitingou, UNSTIM (Bénin) \\ Corresponding Author*
}

\begin{abstract}
The gradual decline in the level of learners is one of the main difficulties currently facing education in Benin. While numerous efforts are being made by socio-political stakeholders, there is limited scientific documentation on the real causes of this scourge. This study aims at identifying the main causes of the drop in level of trainees in Benin's high schools and Colleges. The study was carried out at the "Collège d'Enseignement Général" (CEG) of Fonkpamè in Benin. The research methodology was based on the analysis of trainees' academic results over a period of three years and on semi-structured interviews with a sample of 50 teachers and 120 trainees. The outcomes was a drop in academic performance between 2012-2013 and 2014-2015 at both level 1 and level 2 with increasingly high dropout rates. Highlighting the associated parameters to this drop in level revealed that $74 \%$ of learners with a home away from their school, $66 \%$ of learners with an illiterate parent, $72 \%$ of learners having no access to school books and reinforcement, $91 \%$ of learners paying their own school fees, $84 \%$ of learners who admit to having regular and uncontrolled access to social networks and $68 \%$ of learners without any follow-up from their parents, $70 \%$ of learners aged 15-17 in 5th form did not obtain the average. Hence, these factors have an impact on the academic performance of trainees. It would be important to extend this study to other high schools and colleges in Benin in order to take general measures of pedagogical, didactic, technical and social reforms to improve the performance of the Beninese educational system.
\end{abstract}

Keywords: drop in level, Benin, CEG Fonkpamè, academic results.

\section{INTRODUCTION}

$\mathrm{F}^{\circ}$ or several years, Benin has been following a quality policy to ensure a better performance of its educational system. There have been clear improvements in terms of school attendance. The Gross Enrolment Rate (GER) in elementary school was $50 \%$ in $1970,68 \%$ in $1980,71 \%$ in 1992 and $93 \%$ in 2004(RESEN, 2005). In secondary education, the GER was about $12 \%$ in 1992 but rose to $27 \%$ in 2004. Concurrently, new curricula based on skills development were introduced in 1990 in order to optimize the relationship between the curriculum and the country's social and cultural realities (Agbodjogbéet al., 2013).

Despite technical, financial and institutional support for the implementation of the Competency-Based Approach, an increasing decline in the level of learners is being reported.
Using World Bank data from 2002, Napporn, (2013) found that only $7 \%$ of pupils enrolled in basic courses reached the final year of secondary school. In 2002, the promotion rate in primary education was $70.8 \%$ and the drop-out rate was $8.3 \%$ (Affo, 2004). The Education Sector Review (RSE, 2008) reports a Gross Enrolment Rate in primary school of $98 \%$, a primary school completion rate of $66 \%$, a transition rate of $77 \%$ between fifth and sixth grader classes; and $65 \%$ between ninth and tenth grader classes for $2007.30 \%$ of $5^{\text {th }}$ grade students leave school with difficulty in reading and writing properly. The pass rates for the BEPC in Benin were $49.8 \%$ in $2009,45.8 \%$ in $2010,45.0 \%$ in $2011,31.7 \%$ in 2012 and $49.7 \%$ in 2013 . The statistics for the baccalaureate over the same period are $36.0 \%, 35.3 \%, 28.5 \%, 37.2 \%$ and $32.4 \%$ respectively (Karsenti, 2016).

These data confirm the worrying issue of the drop in the level of trainees. A few studies undertaken by Beninese researchers have looked into this declining level of learners and its possible causes. A study by Attenoukou(Karsenti, 2016) attempted to establish a link between the academic results of learners in high schools and colleges in Porto-Novo and the media and soap operas. Other actors in the educational system rather mention the drop in the level of the teachers themselves (LM, 2013). Technical shortcomings in the implementation of the Competency-Based Approach are also mentioned. The entire subject is complex and it seems difficult to pinpoint responsibilities. A precise diagnosis and objective analysis are All the above motivates us to investigate the real reasons for the drop in the level of learners in Benin's high schools and colleges with a view to propose solutions. The College of Fonkpamè was chosen as experimental site.

\section{STUDY DESIGN}

\section{i. Framework}

Fonkpamè's College is located into Djidja's municipality, within the district of Agondji in Benin. It has sixteen (16) educational groups from the sixth $\left(6^{\text {th }}\right)$ to the last year $\left(12^{\text {th }}\right)$ of schooling.

ii. Methods

1. Study sample 
The study sample is made up of all the pupils of the chosen College.In total, the questionnaire was administered to 50 teachers and 120 students

2. Gathering of administrative, pedagogical and sociodemographic data

Data such as the number of pupils per class, their distribution by sex and promotion, the availability and condition of furniture, the composition of the staff were collected from the managing staff of Fonkpamè's College.

\section{Gathering data on the drop in level}

Data on dropout was obtained by administering a questionnaire to learners and teachers and then analyzing the learners' academic performance.

\section{- Assessment of teachers' knowledge on learners' dropout}

A questionnaire was administered to a sample of fifty (50) teachers. Information was sought on the teacher's teaching practices, their profile and the decline in learner achievement.

\section{- Evaluation of the level of knowledge of learners}

A questionnaire was completed by a sample of one hundred and twenty (120) learners from the College. Information relating to the working conditions ofthe learner and the socioprofessional status of the students' parents was sought.

- Analysis of the learners' academic results from 2013 to 2015

Progression to the next grade and BEPC results from 20122013 to 2014-2015 were collected and analyzed.

\section{- Parameters determining the drop in level}

The parameters determining the drop in level were assessed on a sample of 50 learners. These were distance from home to school, intellectual level, access to curriculum books and reinforcement, school contribution and fees for photocopies, learners' professional qualifications, social networks and television, follow-up and age.

The relationship between each of these parameters and the average scoreobtained by the learner in the 2015-2016 academic year.

\section{DATA PROCESSING AND STATISTICS}

The results were inserted into the Excel software. Means and percentage were calculated.

\section{RESULTS AND DISCUSSION}

Results

1. Administrative, pedagogical and socio-demographic data from Fonkpamè's College

\section{- $\quad$ Students distribution}

Table I presents the distribution of learners in the College by class and by sex. In 2015-2016, it counted 595 learners, including 387 boys and 198 girls. The class with the highest number of students is the sixth grade $\left(6^{\text {th }}\right)$ with 1.37 students, while the class with the lowest number of students is the eleventh grade $\left(11^{\text {th }}\right)$ with 32 students.

Table I: Headcount of Fonpkamè's College student in year 2015-2016

\begin{tabular}{|c|c|c|c|}
\hline Class range & Boys & Girls & Total \\
\hline $6^{\text {th }}$ & 59 & 78 & 137 \\
\hline $7^{\text {th }}$ & $\cdot 42$ & 33 & 75 \\
\hline $8^{\text {th }}$ & 61 & 23 & 84 \\
\hline $9^{\text {th }}$ & 87 & 41 & 128 \\
\hline $10^{\text {th }}$ & 29 & 09 & 38 \\
\hline t1 $^{\text {th }}$ & 24 & 08 & 32 \\
\hline $1^{\text {th }}$ & 86 & 06 & 92 \\
\hline Total & 397 & 198 & 595 \\
\hline
\end{tabular}

\section{- Furnishings}

The furniture consists of two hundred and thirty-five (235) two-seat desks for the students and sixteen (16) desks for the administrative staff. With an enrolment of 595 learners, it appears that 125 learners do not have a seat.

\section{- Administrative staff}

The administrative staff consists of a Headmaster, a Principal, a General Supervisor, a Deputy General Supervisor, an accountant, a secretary and a gatekeeper.

\section{- Teaching staff in class context}

The teaching staff of Fonkpamè's College is made up of 62 teachers in nine (9) different disciplines: French, History and Geography, Mathematics, Physics, Chemistry and Technology, Life and Earth Sciences, Spanish, English, Economics and Physical and Sports Education. 92\% of the teachers are temporary teachers while $8 \%$ are State Contractual Agents (SCA). There are no Permanent State Teachers (PST) (Table II).

Table II: Fonkpamè's College teaching staff

\begin{tabular}{|c|c|c|c|c|}
\hline Disciplines & $\begin{array}{c}\text { Headc } \\
\text { ount }\end{array}$ & PST & SCA & $\begin{array}{c}\text { Part- } \\
\text { time }\end{array}$ \\
\hline French & 12 & 00 & 00 & 12 \\
\hline History and Geography & 09 & 00 & 00 & 09 \\
\hline Mathematics & 12 & 00 & 01 & 11 \\
\hline $\begin{array}{c}\text { Physics, Chemistry and } \\
\text { Technology }\end{array}$ & 04 & 00 & 02 & 02 \\
\hline Life and Earth Sciences & 06 & 00 & 02 & 04 \\
\hline Spanish & 03 & 00 & 00 & 03 \\
\hline Philosophy & 03 & 00 & 00 & 03 \\
\hline English & 05 & 00 & 01 & 04 \\
\hline Economy & 02 & 00 & 00 & 02 \\
\hline $\begin{array}{c}\text { Physical and Sports } \\
\text { Education }\end{array}$ & 06 & 00 & 00 & 06 \\
\hline Total & 62 & 00 & 06 & 56 \\
\hline
\end{tabular}




\section{Decline in the level of learners in secondary education}

\section{- Questionnaire recovery rate}

Forty-six (46) out of 50 questionnaires were collected from teachers, while 96 out of 120 were collected from learners, i.e. recovery rates of $92 \%$ and $80 \%$ each.

\section{- Passing results of Levels I and II.}

Passage results for the years 2012-2013 to 2014-2015 have been collected and are contained in Tables III to VII.
Between 2012 and 2015, the pass rates remained within the range of $\mathbf{5 7 . 5 5 \%}$ and $\mathbf{4 7 . 1 2 \%}$ for Level I (Table III, IV and V). In Level I, the highest number of dropouts was recorded in 2014-2015 with 128 students, including 57 in the sixth grade, giving up school (Table V).

At Level II, from 2012 to 2015, there was a drop in the pass rate falling from $41.70 \%$ in the 2012-2013 academic year (Table VI) to 30\% in the 2014-2015 academic year (Table VII). The highest number of dropouts was recorded in 20142015 where 27 students including 10 in the senior class have withdrawn (Table VII).

Table III: Level 1 passing statistics from 2012 to 2013

\begin{tabular}{|c|c|c|c|c|c|c|c|}
\hline Classes & Headcount & Mean & Moy $\geq 10$ & $\%$ & M $\leq 10$ & $\%$ & Dropout \\
\hline $6^{\text {th }}$ & 103 & 85 & 68 & $80 \%$ & 17 & $20 \%$ & 18 \\
\hline $7^{\text {th }}$ & 94 & 83 & 55 & $66,26 \%$ & 28 & $23,74 \%$ & 11 \\
\hline $8^{\text {th }}$ & 95 & 75 & 39 & $52 \%$ & 36 & $48 \%$ & 20 \\
\hline $9^{\text {th }}$ & 117 & 108 & 40 & $37,09 \%$ & 68 & $62,17 \%$ & 09 \\
\hline Total & 409 & 351 & 202 & $57,55 \%$ & 149 & $42,45 \%$ & 58 \\
\hline
\end{tabular}

Table IV: Level 1 passing statistics from 2013 to 2014

\begin{tabular}{|c|c|c|c|c|c|c|c|}
\hline Classes & Headcount & Mean & Moy $\geq 10$ & $\%$ & Moy $\leq 10$ & $\%$ & Dropout \\
\hline $6^{\text {th }}$ & 96 & 87 & 48 & $70 \%$ & 39 & $44,83 \%$ & 09 \\
\hline $7^{\text {th }}$ & 107 & 90 & 65 & $63,34 \%$ & 25 & $36,66 \%$ & 17 \\
\hline $8^{\text {th }}$ & 94 & 82 & 55 & $58,53 \%$ & 33 & $41,47 \%$ & 12 \\
\hline $9^{\text {th }}$ & 121 & 106 & 25 & $23,58 \%$ & .81 & $76,42 \%$ &. \\
\hline Total & 418 & 365 & 193 & $52,88 \%$ & 172 & $47,12 \%$ & 53 \\
\hline
\end{tabular}

Table V: Level 1 passing statistics from 2014 to 2015

\begin{tabular}{|c|c|c|c|c|c|c|c|}
\hline Classes & Headcount. & Mean. & Moy $\geq 10$ & $\%$ & Mọy $\leq 10$ & $\%$ & Dropout \\
\hline $6^{\text {th }}$ & 148 & 91 & 65 & $71,42 \%$ & 33 & $28,58 \%$ & 57 \\
\hline $7^{\text {th }}$ & 71. & 55 & 38 & $69 ; 04 \%$ & 17 & $30,96 \%$ & 16 \\
\hline $8^{\text {th }}$ & 92 & 70 & 48 & $68,57 \%$ & 22 & $31,43 \%$ & 22 \\
\hline $9^{\text {th }}$ & 136 & 103 & 32 & $31,06 \%$ & 71 & $689,94 \%$ & 33 \\
\hline Total & 447 & 319 & 183 & $57,37 \%$ & 136 & $42,63 \%$ & 128 \\
\hline
\end{tabular}

Table VI: Level 2 passing statistics from 2012 to 2013

\begin{tabular}{|c|c|c|c|c|c|c|c|}
\hline Classes & Headcount & Mean & Moy $\geq 10$ & $\%$ & Moy $\leq 10$ & $\%$ & Dropout \\
\hline $10^{\text {th }}$ & 59 & 43 & 29 & $67,46 \%$ & 14 & $32,54 \%$ & 16 \\
\hline $11^{\text {th }}$ & 58 & 55 & 25 & $45,55 \%$ & 30 & $54,45 \%$ & 03 \\
\hline $12^{\text {th }}$ & 64 & 58 & 11 & $18,96 \%$ & 47 & $81,04 \%$ & 06 \\
\hline Total & 181 & 156 & 65 & $41,70 \%$ & 91 & $58,30 \%$ & 25 \\
\hline
\end{tabular}

Table VII: Level 2 passing statistics from 2014 to 2015

\begin{tabular}{|c|c|c|c|c|c|c|c|}
\hline Classes & Headcount & Mean & Moy $\geq 10$ & $\%$ & Moy $\leq 10$ & Dropout \\
\hline $10^{\text {th }}$ & 15 & 11 & 10 & $90,90 \%$ & 01 & $9,10 \%$ & 04 \\
\hline $11^{\text {th }}$ & 38 & 33 & 19 & $57,57 \%$ & 14 & $42,43 \%$ & 05 \\
\hline $12^{\text {th }}$ & 94 & 76 & 07 & $09,25 \%$ & 69 & $90,75 \%$ & 10 \\
\hline Total & 147 & 120 & 36 & $30 \%$ & 84 & $70 \%$ & 27 \\
\hline
\end{tabular}


- Results of the "Brevet d'Etude du Premier Cycle" $(B E P C)$

From 2012-2013 to 2014-2015, there was a gradual decline in the percentage of BEPC successes, which fell from $40.75 \%$ to $25 \%$ respectively, i.e. an average success rate of $33 \%$ over the three years (Table VIII).

Table VIII: BEPC results for the last three years

\begin{tabular}{|c|c|c|c|}
\hline Academic year & Headcount & Mean & Frequencies \\
\hline $2012-2013$ & 135 & 55 & $40,75 \%$ \\
\hline $2013-2014$ & 148 & 48 & $32,44 \%$ \\
\hline
\end{tabular}

\begin{tabular}{|c|c|c|c|}
\hline $2014-2015$ & 120 & 30 & $25 \%$ \\
\hline Total & 403 & 133 & $33 \%$ \\
\hline
\end{tabular}

\section{- Parameters determining the drop in level}

From the surveys, the parameters likely to determine the drop in the level of the learners were assessed.These were distance from home to school, intellectual level, access to curriculum books and reinforcement, school fees and photocopying costs, Teachers professional qualifications, social Medias and TV, follow-up and age.

Table IX: Parameters determining the drop in level

\begin{tabular}{|c|c|c|c|c|c|c|}
\hline & \multirow{2}{*}{\multicolumn{2}{|c|}{ PARAMETERS }} & \multicolumn{2}{|c|}{ Means $<10$} & \multicolumn{2}{|c|}{ Means $\geq 10$} \\
\hline & & & $\mathrm{n}$ & $\%$ & $\mathrm{n}$ & $\%$ \\
\hline A & DISTANCES & Far from College & 37 & $74 \%$ & 13 & $26 \%$ \\
\hline \multirow[b]{2}{*}{ B } & \multirow[b]{2}{*}{ Intellectual level } & Literate Parents & 33 & $66 \%$ & 17 & $34 \%$ \\
\hline & & Illiterate Parents & 11 & $22 \%$ & 39 & $78 \%$ \\
\hline \multirow{2}{*}{$\mathrm{C}$} & \multirow{2}{*}{$\begin{array}{l}\text { Access to curriculum books } \\
\text { and reinforcement }\end{array}$} & Limited access & 24 & $48 \%$ & 26 & $52 \%$ \\
\hline & & Good access & 09 & $18 \%$ & 41 & $82 \%$ \\
\hline \multirow[b]{2}{*}{$\mathrm{D}$} & \multirow{2}{*}{$\begin{array}{c}\text { School fees and } \\
\text { photocopying costs }\end{array}$} & Provide by learners themselves & 45 & $91 \%$ & 05 & $09 \%$ \\
\hline & & Provide by parents & 12 & $24 \%$ & 39 & $78 \%$ \\
\hline $\mathrm{F}$ & Social medias and TV & No access & 12 & $24 \%$ & 38 & $76 \%$ \\
\hline \multirow[b]{2}{*}{ G } & \multirow{2}{*}{ Follow-up } & None & 34 & $68 \%$ & 16 & $32 \%$ \\
\hline & & From parents to teachers & 6 & $12 \%$ & 44 & $88 \%$ \\
\hline \multirow[b]{2}{*}{$\mathrm{H}$} & \multirow[b]{2}{*}{ Age } & Aged $15-17$ in $7^{\text {th }}$ grade & 25 & $70 \%$ & 15 & $30 \%$ \\
\hline & & Aged $11-13$ in $7^{\text {th }}$ grade & 11 & $22 \%$ & 39 & $78 \%$ \\
\hline
\end{tabular}

From the analysis of Table IX, it appears that $74 \%$ of learners living far from their school, $66 \%$ of learners with an illiterate parent, $72 \%$ of learners with no access to school books and reinforcement, $91 \%$ of learners paying the school contribution themselves, $84 \%$ of learners admitting to have regular and uncontrolled access to social networks and $68 \%$ of learners who do not benefit from any follow-up from their parents, $70 \%$ of learners aged $15-17$ in class 5 did not obtain the average.

\section{DISCUSSION}

The aim of this study was to explore the causes of the drop in the level of general secondary education in order to make objective contributions for improving the performance of the Beninese educational system. The 'Collège d' Enseignement General" of Fonkpamè served as site for the research. Our study revealed a drop in school results between 2012-2013 and 2014-2015 at both level 1 and level 2 with increasingly high repeating rates. On the basis of the findings, several assumptions were made to justify the drop in level inside Fonkpamè's College: the distance from home to school, the intellectual level of parents, access to books in the curriculum and reinforcement, school fees and photocopying costs, social networks and television, the follow-up of learners by their parents and age.

\section{- Home-School distance}

$74 \%$ of learners living at a distance from their school did not achieve an average score. This can be explained by the delays and fatigue caused by long distances, which disrupt the learner's academic performance. The results are in line with the ones obtained by Sorgho, (2008) in Ouagadougou, where 
the study carried out at Riale high school and the NaabaZoungrana College in Tenkodogo showed that $14.63 \%$ of the learners are located more than $3 \mathrm{~km}$ from their school. The fact that the studies were not carried out in the same country, nor under the same sociological conditions, makes it impossible to compare them. However, the study reported that walking such a long distance does have some influence on student performance, as it affects the effectiveness of students in revising their lessons in the evenings after school (Sorgho, 2008).

\section{- $\quad$ Parents}

$66 \%$ of learners with an illiterate parent did not achieve the average. This can be explained as illiterate parents have great difficulty in monitoring their children at home. For example, $68 \%$ of learners who do not receive any support from their parents have an average score below 10 . The only favourable setting for the child to express himself and communicate is thus reduced to the school. Sorgho, (2008) tried to establish a relationship between parents' occupation and students' appreciation of their educational conditions. The study showed that most farmers' children (70.27\%) and workers' children $(57.14 \%)$, while a minority of civil servants' children $(37.93 \%)$ and children whose fathers are professionals $(20 \%)$ felt that their living conditions were not an advantage for their studies. Similarly, using data collected in 100 secondary schools in Benin from 1,476 pupils in $9^{\text {th }}$ grade, Djallo, (2009) found, using the propensity score matching method, that the parent-child communication relationship reduces the number of years of failure in the last three school years by 0.30 standard deviations. Yuang, (2013) has shown that parental cultural and educational capital influences pupils' school performance, while the economic situation of pupils' parents does not seem to have any impact on their school success; Schiller et al. (2002) confirm these data by concluding that well-educated parents are better equipped to provide both pedagogical and social support for their children's school success than parents with low levels of education. These data show a relationship between parental occupation and living conditions, which are in turn related to educational outcomes. Nevertheless, it should be pointed out that some parents from wealthy backgrounds do not always take responsibility for their children's academic development. Indeed, very few learners say that parents encourage them to do assignments at home. Moreover, the new pedagogical practices introduced with the Competency Based Approach have seriously confused parents and elders who have been providing tutoring to learners, as they have not been trained in these approaches (Napporn 2013). Being an intellectual parent gives therefore no guarantee that the learner will be followed-up.

\section{- Access to school materials and books}

$72 \%$ of learners with unfavorable access to textbooks did not achieve a grade average. This highlights the importance of documentation in the construction of knowledge and consequently in academic performance, especially in a pedagogical context where the learner is supposed to be the center of knowledge.

Without documentation, learners will find it difficult to be autonomous in constructing their own knowledge as recommended by the Competency-Based Approach. Accordingly, the study conducted by Sorgho, (2008) shows that only $28.05 \%$ of the learners surveyed have access to all school books and textbooks. This lack of school materials can have a negative impact on academic performance, as the availability of books has a positive influence on students' academic performance (Maiga, 1990).

\section{- Excessive use of social media and TV}

Social media and television can be overly distracting, especially since $84 \%$ of learners who admitted that they had regular and uncontrolled access did not achieve a grade. Attenoukou attempted to establish a link between the academic performance of high school and college learners and the media in Porto-Novo, Benin (Karsenti, 2016). It must be said that the data available in the scientific literature on the effects of social networking use are quite contradictory, requiring consideration of additional parameters such as the context of use, the duration of use and the conditions of use. Sharif and Sargent, (2006) have shown in an American study that specific television content, for example unsuitable films for children, has a negative impact on school performance. Dehmler, (2009) explains that media use (TV, phone, computer) can negatively affect sleeping quality, which can lower school performance. On the other hand, in a study from the US, Paik, (2000) found a curvilinear relationship between television use and maths grades. A duration of use between 0 and 1 hour increased the score in Mathematics. Negative effects were only observed after 1 hour of daily use (Paik, 2000).

\section{- School fees and photocopying costs}

$91 \%$ of learners responsible for paying their own school fees performed poorly at school. Indeed, in such conditions, the learners concerned are obliged to carry out income-generating activities in parallel with their academic studies. Time is divided between studies and these activities, which can reduce performance.

\section{- Learners ages}

$70 \%$ of learners aged $15-17$ in the 5 th grade did not obtain the average grade. They are in fact teenagers who are going through a youth crisis that makes them want to assert themselves. A study carried out in Italy correlates school adjustment with difficulties in psychosocial development (Pombeniet al., 2002).

Psychotherapist Guy Scharmann has sufficiently highlighted the phenomenon of school phobia, the prevention of going to school, as a symptom common to many psychological difficulties of varying nature and severity, which often arise in adolescence (Scharmann, 2011) and which can have an impact on school performance. 


\section{- Teacher-related causes}

The qualification of teachers can be a determining factor in the drop in level in general secondary education. The teaching staff of Fonkpamè's College is composed of 62 teachers, 92\% of whom are par-time teachers while $8 \%$ are state contractual agents. $62 \%$ of the students with no qualified teacher (parttime and without a professional diploma) did not obtain the average grade. It is known that quality education requires qualified teachers (EQEQ, 2014). But despite the efforts of education authorities to recruit teachers, the gap in qualified teachers remains. Most studies on teacher experience conclude that it has a positive impact on learning outcomes, but very few show a significant impact (Ballarbre, 2010). In interviews, some learners claimed that teachers' behaviors were a demotivating factor for them to learn. Some even argued that their teacher is too interested in small stories. All these points need to be taken into account in order to know that teachers have their share of responsibility for the causes of the drop in learners' level.

\section{CONCLUSION}

The gradual decline in the level of learners in secondary schools is a particular phenomenon. Our study has shown that there is a relationship between the drop in level and several parameters, including distance from home to school, parents' intellectual level, access to and reinforcement of curriculum books, school fees and photocopying costs, learners' professional qualifications, social networks and television, follow-up and age. Il There is an urgency to extend this study to other high schools and colleges in Benin so as to optimize the state of the art on the drop in the level of learners in order to propose reforms and strategies to improve the performance of the Beninese education system.

\section{REFERENCES}

[1] Rapport d'État sur le Système Éducatif National. (2005). Eléments de synthèse de l'étude : Le système béninois; Performance et espaces d'amélioration pour la politique éducative.https://dakar.iiep.unesco.org/sites/default/files/fields/pub lication_files/synthese resen benin 0 .pdf

[2] Agbodjogbé, B., Amade-Escot, C. et Attiklèmè, K. (2013). La réforme des curriculums par compétences au Bénin: Le point de vue des acteurs en éducation physique et sportive et en Sciences de la Vie et de la Terre.Éducation et socialisation, 34.
[3] Napporn, C. et Baba-Moussa A. (2013). Accompagnement et soutien scolaires: l'expérience béninoise.Revue internationale d'éducation de Sèvres, 62(1), 79-88.

[4] Affo, M. A. (2004). Promotion de la scolarisation des enfants au Bénin: le département du Mono, un exemple de réussite.https://www.yumpu.com/fr/document/view/16854499/pro motion-de-la-scolarisation-des-enfants-au-benin-colloque-

[5] Revue du secteur de l'éducation. (2008), Memorandum.

[6] Karsenti, T. Mieux former les enseignants dans la Francophonie. Principaux enjeux actuels et futurs, Montréal.file:///C:/Users/ASSOGBA\%20Ph\%C3\%A9nix/Downlo ads/Improving teacher training in Francophone contexts insigh ts for_education planners.pdf

[7] LM. (2013). Baisse de niveau des écoliers dans le Zou: Les Directeurs d'école accusent les Normaliens. http://news.acotonou.com/h/11988.html.

[8] Sorgho, R. (2008). Origine sociale et performances scolaires: analyse de l'influence des facteurs socio- économiques sur les résultats scolaires. Etude de cas du lycée Rialé et du collège Naaba Zoungrana de Tenkodogo.Mémoire de Maitrise, Université de Ouagadougou, UFR- SH, Département de sociologie.

[9] Djallo, A. (2009). Impact de l'action parentale sur la performance scolaire au Bénin : relation communicationnelle, suivi des études et incitation à l'excellence, Mémoire de fin de formation pour l'obtention du Master en Économie Publique et Statistique Appliquée.

[10] Yuang, 2003.

[11] Schiller, S.,Khmelkov, T. et Wang, X. (2002). Economic Development and the Effects of Family Characteristics on Mathematics Achievement.Journal of Marriage and Family, 64(3), 730-742.

[12] A. MAIGA, 1990.

[13] Sharif, I. et Sargent, J. D. (2006). Association Between Television, Movie, and Video Game Exposure and School Performance.Pediatrics, 118(4), e1061-e1070.

[14] Dehmler, K. (2009). Adolescent technology usage during sleeptime: does it influence their quality of sleep, attention difficulties and academic performance? $\mathrm{PhD}$ Thesis, https://scholarworks.rit.edu/theses/6829/.

[15] Paik, H. (2000). Television Viewing and High School Mathematics Achievement: A Neural Network Analysis. Quality\&Quantity, 34(1), 1-15.

[16] Pombeni, M. L.,Zappal, S. et Guglielmi, D. (2002). Expérience scolaire et développement psychosocial: une recherche sur les adolescents. L'orientation scolaire et professionnelle, 31(3).

[17] Scharmann, G.(2011). Rejets d'école à l'adolescence.Enfances\& Psy, 52, 78-88.

Une éducation de qualité nécessite des enseignants qualifiés », UNESCO, 03-oct2014.Availableon:https://fr.unesco.org/news/\%C3\%A9ducationqualit\%C3\%A9-n\%C3\%A9cessite-enseignants-qualifi\%C3\%A9s. [Consulté le: 07-nov-2018].

[18] Bellarbre, E. Caractéristiques des enseignants et réussite scolaire. $59 \mathrm{p}$ 